\title{
A kinda e a misanga: encontros brasileiros com a literatura angolana
}

\author{
DÉBORA LeITE DaVID ${ }^{1}$ \\ Universidade de São Paulo
}

as margens angolanas e brasileiras desse imenso Atlântico podemos buscar numerosas marcas da perene travessia de fraternas semelhanças. Para além de partilhar a língua portuguesa, herança comum de forte ligação, Angola e Brasil empreenderam movimentos culturais e críticos por meio de seus intelectuais e escritores, que viriam consolidar o trânsito de pensamentos e utopias entre as duas pátrias irmãs no decorrer do século XX. Se de um lado os angolanos buscavam subsídios no repertório literário brasileiro que lhes fossem valiosos para fortalecer o seu sistema literário nacional, e em certa medida o seu "projeto nacional", de outro lado, os brasileiros intensificavam o resgate das origens africanas que permeiam as suas identidades.

Dessas travessias nasce a história do recente lançamento A kinda e a misanga: encontros brasileiros com a literatura angolana, organizado por Rita Chaves, Tania Macêdo e Rejane Vecchia (São Paulo: Cultura Acadêmica/Luanda, Angola: Nzila, 2007). Mais do que uma coletânea de ensaios de professores brasileiros sobre a literatura angolana, $A$ kinda e a misanga recupera um tempo nem tão distante assim, quando poucos estudiosos se dedicavam ao ensino e à investigação no campo das literaturas africanas de língua portuguesa. Sugestão do escritor José Luandino Vieira por ocasião de sua visita ao Brasil em 1990, a idéia era organizar uma antologia que indicasse a presença dos estudos críticos e literários relativos a Angola nas universidades brasileiras. Apesar de finalizada, não foi possível a sua publicação, em razão da guerra civil que se intensificou em Angola (1992), quando se perdeu todo o material. Recupera-

\footnotetext{
1 Doutoranda em Estudos Comparados de Literaturas de Língua Portuguesa na Universidade de São Paulo (USP) e bolsista CNPq.
} 
dos parcialmente os textos da antologia original, retomou-se o projeto anterior, mas desta feita ampliado, para abarcar o crescimento do interesse pelo estudo das literaturas africanas de língua portuguesa desde então.

A kinda e a misanga, título escolhido pelas organizadoras, retoma o sentimento de camaradagem encontrado no romance João Vêncio - os seus amores, de Luandino Vieira, esse "fazer o nosso colar de contas amigadas". A antologia é apresentada em duas partes. Na primeira parte estão os ensaios do projeto original interrompido em 1992, cujos textos trazem "recortes de um contexto marcado por perspectivas teóricas que abriram os caminhos à Literatura Angolana entre os brasileiros".

Desses textos coligidos há quase duas décadas, percebemos uma linha crítica voltada para temas pertinentes à autodeterminação nacional e literária de Angola. Abordando temas como angolanidade, nação, ethos revolucionário, identidade, autonomia da literatura angolana, ficção e guerra, colonialismo e resistência, os professores e críticos brasileiros ocupavam-se principalmente em compreender como a literatura angolana conseguia transcender às limitações nacionalistas de curto fôlego, característica própria de projetos literários nacionalistas e revolucionários. Em quase todos os ensaios encontramos duas obras que se colocam como basilares às discussões teóricas e críticas empreendidas por estudiosos como Benjamin Abdala Júnior, Maria Aparecida Santilli e Fernando Mourão, entre outros. Trata-se de Luuanda, de José Luandino Vieira, e Mestre Tamoda, de Uanhenga Xitu, obras que traduzem de maneira ímpar as marcas de transgressão e ruptura em relação à hegemonia cultural e política do colonizador.

Nesse primeiro bloco, destacamos o ensaio "O percurso da angolanidade: do século XIX a Arnaldo Santos”, de Benilde Justo Caniato. Em detida análise sobre as mais tenras manifestações literárias de periódicos em Angola, a ensaísta traz à luz os caminhos trilhados para a construção da angolanidade. Desde os primeiros sinais na atividade jornalística, ainda na primeira metade do século XIX, a angolanidade será o fio condutor e a expressão da construção de uma consciência nacional que impulsionou o movimento de libertação de Angola das amarras coloniais. Caráter esse que explica, de certa forma, os "travos de militância" atribuídos à literatura angolana e à crítica construída ao longo das últimas três décadas.

A segunda parte, por sua vez, reúne ensaios que demonstram a presença marcante dos estudos sobre a literatura angolana em várias universidades 
brasileiras atualmente. Percebemos, nesses ensaios, um novo horizonte crítico que se alinha com pontos teóricos contemporâneos como os estudos pós-coloniais, sem, contudo, deixar de explorar questões como a relação das africanas de língua portuguesa com a tradição oral e com a História.

Podemos apontar como fio condutor desses ensaios um novo caminho crítico que parece buscar uma separação entre a crítica brasileira contemporânea e o estigma da literatura engajada. Por meio de análises que se debruçam sobre as mais variadas obras e autores angolanos, os críticos procuram compreender os caminhos percorridos pela literatura angolana na sua auto-afirmação e expansão no período pós-independência. Deixam de se deter nas marcas revolucionárias para explorar as transformações operadas na intelectualidade angolana com a destruição das amarras coloniais e a reinvenção do passado para a construção de um novo futuro.

Entre os autores da segunda parte da antologia, destacamos Mário César Lugarinho, com o ensaio "Quem deve comer lagostas? Reflexões sobre os estudos pós-coloniais a partir de alguma ficção de Pepetela e Agualusa”. Encontramos nesse texto um relevante cotejo entre dois autores e suas obras, em que é possível destacar a contraposição polêmica da identidade nacional utópica, construída a partir de uma nação emergida dos conflitos da guerra colonial e das disputas internas pelo poder, e do seu questionamento, que surge de maneira veemente na obra de Agualusa, parecendo dedicar-se esse autor a demonstrar a falência de um projeto nacional.

Como vemos, trata-se de uma antologia riquíssima, não apenas por sua importância no mapeamento e no registro da história dos estudos sobre a literatura angolana no Brasil, como também pela pluralidade de autores e pela diversidade de pontos de vista teóricos presentes nos ensaios coligidos, demonstrando o diálogo cada vez mais intenso firmado no campo da crítica literária brasileira sobre Angola e sua literatura. 